\section{Foliar- and Fruit-applied Strontium as a Tracer for Calcium Transport in Apple Trees}

\author{
Carl J. Rosen, Peter M. Bierman, Adriana Telias, and Emily E. Hoover \\ Department of Soil, Water, and Climate and Department of Horticultural \\ Science, 1991 Upper Buford Circle, St. Paul, MN 55108
}

Additional index words. bitter pit, adjuvant, foliar sprays

\begin{abstract}
Application of calcium (Ca) sprays is a recommended practice to reduce the incidence of Ca-related disorders such as bitter pit in apple (Malus $\times$ domestica), but effectiveness of sprays to increase Ca concentrations in the fruit is not always consistent. Strontium (Sr) has been used as a $\mathrm{Ca}$ analog to evaluate $\mathrm{Ca}$ transport processes and distribution in plants. A field study was conducted using foliar- and fruit-applied $\mathrm{Sr}$ as a tracer for $\mathrm{Ca}$ transport in 20-year-old 'Honeycrisp' apple trees on Malling.26 (M.26) rootstock. The objectives of this study were to 1) measure the amount of $\mathrm{Sr}$ translocation from leaves to fruit, 2) determine the effectiveness of eight sprays applied over the growing season vs. four late-season sprays on increasing Sr concentrations in leaves and fruit, and 3) evaluate the effect of an experimental adjuvant consisting of alkyl-polysaccharides and monosaccharides on spray efficacy. Seven treatments were tested, which included a control and six Sr treatments applied in various combinations with or without an adjuvant. Trees were sprayed four or eight times during the growing season, either directly to leaves and fruit or to leaves only (fruit covered during application). Spray treatments did not significantly affect total fruit fresh or dry weight. Although some discrimination between $\mathrm{Ca}$ and $\mathrm{Sr}$ was detected, the similar distribution of $\mathrm{Ca}$ and $\mathrm{Sr}$ in fruit tissue of control treatments suggested that $\mathrm{Sr}$ is a suitable tracer for Ca. Based on the covered vs. uncovered fruit treatments, about $11 \%$ to $17 \%$ of the $\mathrm{Sr}$ in the fruit came from $\mathrm{Sr}$ applied directly to the leaves. Eight spray applications over the growing season more than doubled both the concentration and content of fruit $\mathrm{Sr}$ compared with four late season sprays. The tested adjuvant doubled $\mathrm{Sr}$ absorption by and translocation to fruit compared with not using an adjuvant. Assuming similar transport for $\mathrm{Ca}$ and $\mathrm{Sr}$, and adjusting for the atomic weight of $\mathrm{Ca}$ relative to $\mathrm{Sr}$, the maximum increase in fruit Ca concentration at harvest from foliar and fruit applications (eight sprays with adjuvant and uncovered fruit) would have been as follows: core $=78 \mathrm{mg} \cdot \mathrm{kg}^{-1}$; flesh $=35$ $\mathrm{mg} \cdot \mathrm{kg}^{-1}$; peel $=195 \mathrm{mg} \cdot \mathrm{kg}^{-1}$; entire fruit $=67 \mathrm{mg} \cdot \mathrm{kg}^{-1}$. In addition to being an underused tool for studying Ca transport patterns, the results also suggest that use of $\mathrm{Sr}$ may be a novel technique for testing the efficacy of various adjuvants used to enhance uptake and transport of $\mathrm{Ca}$ in leaves and fruit.
\end{abstract}

Quality and storability of apple fruit are often strongly associated with levels of $\mathrm{Ca}$ in fruit (Vang-Petersen, 1980). Of the Ca-related quality problems in apples, bitter pit is one that is particularly challenging to control in certain cultivars. While bitter pit can be controlled to some degree by ensuring an even crop load and maintaining uniform soil moisture, application of Ca sprays through the growing season is often a general recommendation to minimize incidence of the disorder (Ferguson and Watkins, 1989).

Evaluating the effects of foliar and fruit $\mathrm{Ca}$ applications is often problematic, because it is difficult to determine the extent of $\mathrm{Ca}$ absorption in tissue from the sprays. Without any Ca treatment, apple fruit Ca concentrations can vary by as much as 2 - to 3 -fold within the same tree (Perring and Jackson, 1975). Only small amounts (about 1 to $2 \mathrm{mg}$ Ca per fruit) are needed to improve storage quality (Wilkinson,

Received for publication 25 Aug. 2005. Accepted for publication 25 Sept. 2005. We thank Agriliance LLC (St. Paul, Minn.) and the Minnesota Apple Growers Association for partial funding in support of this research. The assistance ofDavidBedford in maintaining the field site is gratefully acknowledged.
1968). However, relatively large amounts of $\mathrm{Ca}$ are already present in the tissue (about 7 to $11 \mathrm{mg} \mathrm{Ca}$ per fruit) and its concentration and content can be affected by crop load, fruit size, weather, and other factors (Ferguson and Watkins, 1992; Perring and Jackson, 1975). Increasing the number of replications and number of fruit sampled would be methods of dealing with the high variability of fruit $\mathrm{Ca}$, analytical costs. Using ${ }^{45} \mathrm{Ca}$ would be another method to evaluate effectiveness of foliar sprays, but cost and permitting concerns make a field study using radioactive $\mathrm{Ca}$ impractical. Van Goor (1973) used fruit-applied ${ }^{45} \mathrm{Ca}$ in a lab and pot study to show the extent of $\mathrm{Ca}$ penetration through the peel.

Strontium ( $\mathrm{Sr}$ ) is an element with chemical properties that are similar to those of $\mathrm{Ca}$, yet is found naturally in much lower amounts in soil and plant tissue. While radioactive $\mathrm{Sr}\left({ }^{9} \mathrm{Sr}\right)$ is a major health concern, stable $\mathrm{Sr}$ (atomic weight of 88 ) at low to moderate concentrations is considered relatively nontoxic to plants and animals (ATSDR, 2004; Kabata-Pendias and Pendias, 2001). Because of their similarities, use of $\mathrm{Sr}$ as a tracer for $\mathrm{Ca}$ has been reported in but these approaches also increase labor and plant studies to understand Ca transport patterns (Laszlo, 1994). Plant uptake, transport, and distribution of Ca and Sr have been shown to be similar, although Sr was not able to completely substitute for $\mathrm{Ca}$ in metabolic or physiological processes (Hutchin and Vaughan, 1968; Queen et al., 1963).

Studies to simulate radioactive fallout have been conducted to determine the extent of $\mathrm{Sr}$ translocation to and absorption by fruit following foliar application with ${ }^{85} \mathrm{Sr}$ (Bengtsson, 1992; Carini and Bengtsson, 2001; Carini et al., 2003). In general, translocation of ${ }^{85} \mathrm{Sr}$ to fruit following application was found to be minimal or nonexistent. In studies with apples, almost all radioactivity was restricted to the peel tissue and was attributed to direct application to the fruit (Bengtsson, 1992).

Wills et al. (1975) reported that Sr salts applied to apple fruit reduced the incidence of internal breakdown and bitter pit compared with those not treated, but that $\mathrm{Sr}$ applications were no more effective than $\mathrm{Ca}$ applications. Conway and Sams (1987) found that Ca was more effective than $\mathrm{Sr}$ in reducing fruit decay caused by Penicillium expansum when results were expressed on a weight basis of element applied. When expressed on a molar basis, however, the effect of the two cations on fruit decay was similar. Siddiqui and Bangerth (1995) reported no differences in fruit firmness at harvest following foliar applications of $\mathrm{Ca}$ and $\mathrm{Sr}$, but after $20 \mathrm{~d}$ in storage fruit from $\mathrm{Ca}$-treated branches were firmer and higher in pectins than those from Sr-treated branches.

While the effects of Sr on apple fruit firmness and bitter pit have been evaluated, the use of $\mathrm{Sr}$ as a tracer for foliar and fruit applications of Ca has not. Therefore, this study used foliarand fruit-applied $\mathrm{Sr}$ as a tracer for Ca transport with the following objectives: 1) measure the amount of Sr translocation from leaves to fruit, 2) determine the effectiveness of eight sprays applied over the growing season vs. four late season sprays on increasing $\mathrm{Sr}$ concentrations in leaves and fruit, and 3) evaluate the effect of an experimental adjuvant on spray efficacy. 'Honeycrisp' was chosen as the test cultivar for this study because of its susceptibility to bitter pit (Rosenberger et al., 2004).

\section{Materials and Methods}

This research was conducted in 2003 at the University of Minnesota, Horticultural Research Center in Chanhassen, on a single row of 20year-old 'Honeycrisp' trees on M.26 rootstock spaced $3.1 \mathrm{~m}$ apart within rows. Trees were grown on a Hayden loam soil (Fine-loamy, mixed, superactive, mesic Glossic Hapludalfs) with the following chemical properties ( 0 to 25 $\mathrm{cm}): \mathrm{pH}(1$ soil : 1 water $)=6.3$; organic matter $=3.5 \%$; Bray $1 \mathrm{P}=11 \mathrm{mg} \cdot \mathrm{kg}^{-1} ; 1 \mathrm{~N}$ ammonium acetate extractable $\mathrm{K}, \mathrm{Mg}, \mathrm{Ca}$, and $\mathrm{Sr}=147$, 352,2202 , and $4.5 \mathrm{mg} \cdot \mathrm{kg}^{-1}$, respectively (Brown, 1998). The nearly 500-fold higher availability of soil $\mathrm{Ca}$ compared with $\mathrm{Sr}$ on a weight basis ( $>1000$-fold higher availability on an atom basis) suggests that foliar-applied $\mathrm{Sr}$ could be a suitable tracer for $\mathrm{Ca}$, assuming that transport properties in the plant are similar. 
The following seven treatments were tested:

1) Control (no Sr applied).

Sprays applied over the growing season on eight occasions.

2) Sr without adjuvant, fruit covered during spray application.

3) Sr without adjuvant, fruit uncovered during spray application.

4) $\mathrm{Sr}+$ adjuvant, fruit covered during spray application.

5) $\mathrm{Sr}+$ adjuvant, fruit uncovered during spray application.

Late-season sprays applied on four occasions.

6) $\mathrm{Sr}+$ adjuvant, fruit covered during spray application.

$\mathrm{Sr}+$ adjuvant, fruit uncovered during spray application.

Arow of 14 trees planted in a north to south direction was divided so that there were two blocks on the east side of the trees and two blocks on the west side, allowing each treatment to be replicated four times in a randomized complete block design. A block consisted of seven half trees and each half tree was considered a plot. A treatment was assigned on the east side of the tree as part of one block and a treatment was assigned on its west side as part of another block. Each treatment within a block was applied to a single branch. Branch sections of 1 to $2 \mathrm{~m}$ in length with at least 10 to 12 blossom clusters were selected and tagged at the beginning of the study.

Strontium spray solutions were mixed using $\mathrm{Sr}\left(\mathrm{NO}_{3}\right)_{2}$ as the Sr source (Fisher Scientific, Pittsburgh, Pa.). The nitrate source was selected because many popular $\mathrm{Ca}$ products available in the midwestern U.S. use $\mathrm{Ca}\left(\mathrm{NO}_{3}\right)_{2}$ as the primary source of $\mathrm{Ca}$. The concentration of $\mathrm{Sr}\left(\mathrm{NO}_{3}\right)_{2}$ applied was $35 \mathrm{mM}\left(3080 \mathrm{mg} \cdot \mathrm{L}^{-1}\right.$ $\mathrm{Sr}$ ). This was based on concentrations of $\mathrm{Ca}$ (1400 $\mathrm{mg} \cdot \mathrm{L}^{-1}$ ) recommended to control bitter pit. Because the atomic weight of $\mathrm{Sr}$ is about 2.2 times greater than $\mathrm{Ca}$, the $\mathrm{Sr}$ applied was equivalent to $\mathrm{Ca}$ on an atom basis rather than an equivalent weight basis.

The adjuvant tested was an experimental product (Agriliance LLC, St. Paul, Minn.) and mixed at $1 \%$ by volume in those treatments that included an adjuvant. Alkyl-polysaccharides as a surfactant and additional monosaccharides were the primary components of the adjuvant. Spray applications over the growing season were made eight times at about 10- to 14-d intervals, beginning $14 \mathrm{~d}$ after petal fall. The late-season spray schedule included only the last four dates of the eight-spray application schedule. Spray application dates were 10 June, 19 June, 3 July, 15 July, 28 July, 12 Aug., 26 Aug., and 9 Sept.

The entire length of the branch section comprising a plot (main branch + all side branches) was sprayed to runoff with a hand-held spray bottle. For the covered fruit treatment, fruit were enclosed in Whirl-Pak (Nasco, Fort Atkinson, Wisc.) plastic bags immediately before application. The bags were removed as soon as the spray residue on bag surfaces was dry, usually within $1 \mathrm{~h}$ after application.

Leaf samples (10 leaves per plot) and fruit samples (up to 5 fruit per plot) were collected for nutrient analysis on 22 July, which was after the first four spray applications and before the last four late-season spray applications. Therefore, Sr applications for treatments 6 and 7 (late season sprays) had not yet been applied at this first sampling date and they had been treated the same as the control. Fruit and leaf samples were collected again from the same branch after fruit were mature on 23 Sept. (fruit) and 1 Oct. (leaf). Due to uneven fruit drop it was not possible to sample 5 fruit from every plot on both dates, so smaller samples were collected from some plots on the July sampling date to leave the maximum number of fruit for the September sampling of mature fruit. The average crop load on the sprayed branches before the July harvest date was 7 to 8 apples per branch (about $1.5 \mathrm{~m}$ in length). Within $2 \mathrm{~h}$ of sampling, both leaf and fruit samples were soaked in a dilute (1 soap : 60 water) soap solution (VersaClean Detergent, Fisher Scientific) for $30 \mathrm{~s}$ and then rinsed three times in deionized water. The number of apples per plot was counted. Fruit were subdivided using an apple peeler and a knife into peel, flesh, and core samples for analysis. Fresh weight of each fruit part was recorded. Both leaves and fruit parts were dried at $60^{\circ} \mathrm{C}$ until a constant weight was achieved and then the dry weight of each fruit part was recorded. Dried samples were ground with a Wiley mill for leaf, core, and peel tissue and a Stein mill for flesh tissue. Samples were dry-ashed and $\mathrm{Sr}$ and $\mathrm{Ca}$ were determined using an inductively coupled plasma optical emission spectrometer (model 3560; Applied Research Laboratories, Sunland, Calif.) following the procedures of Munter et al. (1984). Data for Sr and Ca in all fruit tissue are expressed on both a con- centration basis $\left(\mathrm{mg} \cdot \mathrm{kg}^{-1}\right)$ and content basis ( $\mu \mathrm{g}$ or mg per fruit tissue). The sum of $\mathrm{Sr}$ and $\mathrm{Ca}$ in the fruit parts, taking into account dry weight differences, was used to calculate the concentration and content of these elements in the whole fruit.

Data were analyzed as a randomized complete block design with a split-plot in time treatment arrangement using the Proc Mixed program in SAS (SAS Institute, 1999). Because of the large differences in Sr concentrations among treatments, all Sr data were log transformed before statistical analysis to determine significance (Steele and Torrie, 1980). Nontransformed means are presented in the tables. The least significant means program in SAS (SAS Institute, 1999) was used to determine differences among treatment means at the 5\% probability level.

\section{Results and Discussion}

None of the treatments tested resulted in visible damage to apple fruit or leaves over the course of the study. Bitter pit was not observed on any of the apples at harvest, including those in the control treatment. Because the primary objective was to determine where $\mathrm{Sr}$ was distributed, the lack of bitter pit incidence did not affect the outcomes of the study and achievement of experimental objectives.

Strontium treatments did not affect fruit fresh or dry weights, except for core samples expressed on a dry weight basis at the September sampling date. The significant Sr treatment effect for core tissue was due to higher core dry weight for Sr applications on uncovered fruit with four sprays $(6.0 \mathrm{~g})$ compared with all other treatments (range was $2.6 \mathrm{~g}$ for Sr without adjuvant, uncovered fruit, eight sprays to 4.3

Table 1. Fruit core, flesh, peel, and whole fruit $($ core + flesh + peel) fresh and dry weights in July and September (averaged over all $\mathrm{Sr}$ treatments).

\begin{tabular}{|c|c|c|c|c|c|c|c|c|}
\hline \multirow{2}{*}{$\begin{array}{l}\text { Sampling } \\
\text { date }\end{array}$} & \multicolumn{4}{|c|}{ Fresh wt (g/fruit) } & \multicolumn{4}{|c|}{ Dry wt (g/fruit) } \\
\hline & Core & Flesh & Peel & Fruit & Core & Flesh & Peel & Fruit \\
\hline 22 July & 14.7 & 32.0 & 7.2 & 53.9 & 2.0 & 4.0 & 1.2 & 7.2 \\
\hline 23 Sept. & 24.0 & 101.8 & 15.6 & 141.4 & 3.6 & 14.5 & 2.7 & 20.8 \\
\hline Significance $^{z}$ & $* *$ & $* *$ & $* *$ & $* *$ & $* *$ & $* *$ & $* *$ & $* *$ \\
\hline
\end{tabular}

${ }^{* *}$ Significant at $P=0.01$.

Table 2. Effect of Sr treatments on leaf Sr and Ca concentrations in July and October

\begin{tabular}{llrr}
\hline $\begin{array}{l}\text { Sampling } \\
\text { date }\end{array}$ & Treatment & $\begin{array}{c}\mathrm{Sr} \\
\left(\mathrm{mg} \cdot \mathrm{kg}^{-1}\right)\end{array}$ & $\begin{array}{c}\mathrm{Ca} \\
\left(\mathrm{g}^{-1} \mathrm{~kg}^{-1}\right)\end{array}$ \\
\hline 22 July & Control & $25 \mathrm{~g}$ & $13.6 \mathrm{~b}^{2}$ \\
& Sr without adjuvant, eight sprays & $2442 \mathrm{e}$ & $14.4 \mathrm{ab}$ \\
& Srwith adjuvant, eight sprays & $3787 \mathrm{c}$ & $11.9 \mathrm{~d}$ \\
& Sr with adjuvant, four sprays & $19 \mathrm{~h}$ & $12.4 \mathrm{~cd}$ \\
1 Oct. & Control & $28 \mathrm{f}$ & $14.6 \mathrm{ab}$ \\
& Sr without adjuvant, eight sprays & $5239 \mathrm{~b}$ & $15.1 \mathrm{a}$ \\
& Sr with adjuvant, eight sprays & $6706 \mathrm{a}$ & $13.1 \mathrm{bc}$ \\
& Sr with adjuvant, four sprays & $2889 \mathrm{~d}$ & $13.3 \mathrm{bc}$
\end{tabular}

${ }^{2}$ Means within a column followed by the same letter are not significantly different at $P=0.05$ using least significant means.

${ }^{\mathrm{y}} \mathrm{Sr}$ treatments were applied after the July sampling date.

Table 3. Fruit core, flesh, peel and whole fruit (core+flesh+peel) calcium concentration $\left(\mathrm{mg} \mathrm{kg}^{-1}\right)$ and content (mg) in July and September (averaged over all Sr treatments).

\begin{tabular}{|c|c|c|c|c|c|c|c|c|}
\hline \multirow{2}{*}{$\begin{array}{l}\text { Sampling } \\
\text { date }\end{array}$} & \multicolumn{4}{|c|}{ Ca concn $\left(\mathrm{mg} \cdot \mathrm{kg}^{-1}\right.$ dry wt) } & \multicolumn{4}{|c|}{$\mathrm{Ca}$ content (mg/fruit) } \\
\hline & Core & Flesh & Peel & Fruit & Core & Flesh & Peel & Fruit \\
\hline 22 July & 1324 & 297 & 740 & 660 & 2.6 & 1.2 & 0.9 & 4.7 \\
\hline 23 Sept. & 1074 & 200 & 507 & 388 & 3.7 & 2.8 & 1.3 & 7.8 \\
\hline Significance & $* *$ & ** & ** & ** & ** & ** & ** & $* *$ \\
\hline
\end{tabular}

${ }^{* *}$ Significant at $P=0.01$. 
$\mathrm{g}$ for Sr with adjuvant, uncovered fruit, eight sprays; the control core dry weight was $2.9 \mathrm{~g}$ ). Reasons for this effect are not known, but the lack of a clear pattern due to $\mathrm{Sr}$ treatment on core dry weight suggests that the effect was circumstantial. Because total fruit fresh and dry weights were not affected by treatment, the means presented are an average over all $\mathrm{Sr}$ treatments at each harvest date (Table 1). As expected, fresh and dry weights of all tissue parts sampled were greater in September than in July. At both sampling dates, the highest proportion of biomass was in the flesh followed by core and then peel.

Covering fruit during spray application did not affect, and was not expected to affect, $\mathrm{Ca}$ or Sr concentrations in leaves. Therefore, covered and uncovered data were pooled to determine $\mathrm{Sr}$ and adjuvant treatment effects on leaf $\mathrm{Ca}$ and $\mathrm{Sr}$ (Table 2). Sampling date and treatment effects, as well as the sampling date by treatment interaction, were significant for leaf Sr. Therefore, interaction effects are presented in Table 2. In July, leaf Sr concentrations were about 1.5 times higher when the adjuvant was used in the spray mixture compared with when the adjuvant was not included in the mixture. Strontium had not been applied to the late season treatments at the time of the July sampling and, therefore, these two treatments were comparable with controls up to this point in the study. In October, the eight $\mathrm{Sr}$ applications with adjuvant resulted in the highest leaf $\mathrm{Sr}$ concentrations, followed by eight $\mathrm{Sr}$ applications without adjuvant. The four late season sprays with adjuvant resulted in leaf $\mathrm{Sr}$ concentrations that were less than half the leaf Sr concentrations when full season sprays with adjuvant were used. In addition, four early Sr sprays with adjuvant (from the full season treatments) resulted in higher leaf Sr concentrations in July compared with leaf Sr concentrations in October from four late season applications. These results suggest that leaf absorption of Sr may be more efficient during the first half of the growing season compared with the second half. Alternatively, leaf dry matter may have been greater in October than in July, which would tend to have a diluting effect on Sr concentrations.

In the control treatment, concentrations of $\mathrm{Ca}$ in leaves were about 500 times greater than
Sr concentrations at both sampling dates. In addition, both elements tended to have higher concentrations in October than in July. The effect of $\mathrm{Sr}$ and adjuvant treatments on leaf Ca concentrations, although significant, cannot be easily explained (Table 2 ). There was a trend for leaf Ca concentrations to be lower when applications of $\mathrm{Sr}$ and adjuvant were used. However, at the July sampling date, the late season treatments had not been applied, so concentrations should have been similar to the true control but were lower. Of interest is the fact that leaf $\mathrm{Sr}$ in this treatment was also lower than leaf $\mathrm{Sr}$ in the true control and was analogous to the Ca response.

Strontium treatments had no effect on fruit Ca concentrations or content in July or at harvest. Therefore, only the sampling date effect is presented in Table 3. Fruit Ca concentrations were lower at harvest (23 Sept.) than in July. In contrast, fruit $\mathrm{Ca}$ content was higher at harvest than at the July sampling date. Consistent with previous reports (Tomala et al., 1989), these results suggest that Ca uptake was still occurring after the July sampling, but that biomass accumulation was occurring at a higher rate and resulted in a lower $\mathrm{Ca}$ concentration in all fruit parts. Calcium concentrations were highest in the core, intermediate in the peel, and lowest in the flesh tissue. The highest fruit Ca content in July and September was in the core and lowest in the peel, reflecting lower biomass accumulation in peel compared to flesh tissue (Table 1).

Strontium concentration and content in all fruit parts individually and combined were significantly affected by treatment, sampling date, and the sampling date by treatment interaction (Table 4). The main source of the interaction was the late season spray treatments, where low $\mathrm{Sr}$ in fruit tissue in July was due to the fact that the actual treatments were not initiated until after the sampling date. Fruit $\mathrm{Sr}$ concentrations increased with $\mathrm{Sr}$ applications for both the July and September sampling dates. The extent of this increase in $\mathrm{Sr}$ concentration depended on adjuvant, whether the fruit was sprayed directly or not, and timing of application. At each sampling date, core, flesh, and peel Sr concentrations were about 2 to 2.5 times higher when the adjuvant was used compared with when the adjuvant was not used. Fruit that were not covered during Sr application had 6 to 10 times higher Sr concentrations than those that were covered. The late season treatments in July were similar to the control treatments, because late season applications had not yet begun at the time of sampling. These results reinforce the importance of directly spraying the fruit and using a suitable adjuvant to increase fruit Ca levels. Of interest, however, is that translocation from leaf to fruit tissue did occur, although the amounts were relatively low compared with direct application to the fruit. At harvest, eight Sr applications with adjuvant resulted in fruit $\mathrm{Sr}$ concentrations that were about three times higher compared with four late season applications with adjuvant.

As with fruit $\mathrm{Sr}$ concentrations, fruit $\mathrm{Sr}$ content increased with $\mathrm{Sr}$ treatments on both the July and September sampling dates and depended on adjuvant, whether the fruit was sprayed directly or not, and timing of application (Table 4). At the July sampling date, the content of $\mathrm{Sr}$ in core, flesh, and peel tissue was about 1.5 times higher when the adjuvant was used compared with when the adjuvant was not used. In September, Sr content was about twice as high when adjuvant was used compared with when adjuvant was not used. Fruit that were not covered during application had 6 to 8 times higher $\mathrm{Sr}$ content than those that were covered (note again that late season application treatments had not yet been sprayed in July and therefore they were comparable to controls up to this point). These results show that some translocation of $\mathrm{Sr}$ from leaf to fruit tissue occurs, but the amounts are relatively low compared with direct application to the fruit. Of the total $\mathrm{Sr}$ in fruit in July or September, $11 \%$ to $17 \%$ came from translocation from sprayed leaves and the remainder was from direct application to the fruit.

Eight spray applications with adjuvant resulted in a fruit $\mathrm{Sr}$ content that was about two times higher compared with four late season applications with adjuvant. Of interest, however, is that four sprays late in the season resulted in higher fruit $\mathrm{Sr}$ content than four sprays early in the season. In part, the advantage of later season applications is a larger apple surface area for absorption. However, even in the covered treatments, Sr content was higher in fruit given four late applications compared

Table 4. Effect of Sr treatments on Sr concentration $\left(\mathrm{mg} \cdot \mathrm{kg}^{-1}\right)$ and content $(\mu \mathrm{g})$ of fruit core, flesh, peel, and whole fruit $(\mathrm{core}+$ flesh + peel).

\begin{tabular}{|c|c|c|c|c|c|c|c|c|c|}
\hline \multirow{2}{*}{$\begin{array}{l}\text { Sampling } \\
\text { date }\end{array}$} & \multirow[b]{2}{*}{ Treatment } & \multicolumn{4}{|c|}{ Sr concn $\left(\mathrm{mg} \cdot \mathrm{kg}^{-1}\right.$ dry wt) } & \multicolumn{4}{|c|}{ Sr content $(\mu \mathrm{g} /$ fruit $)$} \\
\hline & & Core & Flesh & Peel & Fruit & Core & Flesh & Peel & Fruit \\
\hline \multirow{5}{*}{22 July } & Sr, no adjuvant, fruit covered, eight sprays & $11.2 \mathrm{f}$ & $4.0 \mathrm{e}$ & $15.0 \mathrm{f}$ & $7.8 \mathrm{~d}$ & $26 \mathrm{e}$ & $19 \mathrm{~g}$ & $22 \mathrm{~g}$ & $67 \mathrm{~g}$ \\
\hline & $\mathrm{Sr}$, with adjuvant, fruit covered, eight sprays & $22.3 \mathrm{~d}$ & $8.5 \mathrm{~d}$ & $27.9 \mathrm{e}$ & $15.8 \mathrm{~cd}$ & $39 \mathrm{~d}$ & $29 \mathrm{~g}$ & $33 \mathrm{fg}$ & $101 \mathrm{~g}$ \\
\hline & $\mathrm{Sr}$, with adjuvant, fruit uncovered, eight sprays & $172.7 \mathrm{a}$ & $71.3 \mathrm{a}$ & $271.6 \mathrm{ab}$ & $136.7 \mathrm{a}$ & $262 \mathrm{~b}$ & $197 \mathrm{c}$ & $259 \mathrm{~cd}$ & $718 \mathrm{~cd}$ \\
\hline & $\mathrm{Sr}$ with adjuvant, fruit covered, four sprays ${ }^{y}$ & $1.9 \mathrm{~g}$ & $0.7 \mathrm{f}$ & $1.3 \mathrm{~g}$ & $1.1 \mathrm{e}$ & $4 \mathrm{f}$ & $3 \mathrm{i}$ & $1 \mathrm{~h}$ & $8 \mathrm{i}$ \\
\hline & Sr with adjuvant, fruit uncovered, four sprays ${ }^{y}$ & $2.0 \mathrm{~g}$ & $0.8 \mathrm{f}$ & $1.3 \mathrm{~g}$ & $1.2 \mathrm{e}$ & $4 \mathrm{f}$ & $3 \mathrm{i}$ & $2 \mathrm{~h}$ & $9 \mathrm{i}$ \\
\hline \multirow{5}{*}{23 Sept. } & Sr without adjuvant, uncovered, eight sprays & $83.0 \mathrm{~b}$ & $37.6 \mathrm{~b}$ & $133.0 \mathrm{c}$ & $59.7 \mathrm{~b}$ & $211 \mathrm{~b}$ & $460 \mathrm{~b}$ & $383 \mathrm{bc}$ & $1053 \mathrm{bc}$ \\
\hline & Sr with adjuvant, covered, eight sprays & $42.1 \mathrm{c}$ & $13.1 \mathrm{c}$ & $48.8 \mathrm{~d}$ & $22.2 \mathrm{c}$ & $129 \mathrm{c}$ & $175 \mathrm{~cd}$ & $115 \mathrm{e}$ & $419 \mathrm{e}$ \\
\hline & Sr with adjuvant, uncovered, eight sprays & $174.6 \mathrm{a}$ & $78.5 \mathrm{a}$ & $428.1 \mathrm{a}$ & $147.7 \mathrm{a}$ & $736 \mathrm{a}$ & 827 a & $933 \mathrm{a}$ & $2495 \mathrm{a}$ \\
\hline & Sr with adjuvant, covered, four sprays & $15.2 \mathrm{ef}$ & $3.2 \mathrm{de}$ & 17.4 ef & $6.9 \mathrm{~d}$ & $54 \mathrm{~d}$ & $50 \mathrm{f}$ & $48 \mathrm{f}$ & $152 \mathrm{f}$ \\
\hline & Sr with adjuvant, uncovered, four sprays & $39.0 \mathrm{c}$ & $28.5 \mathrm{~b}$ & $211.7 \mathrm{bc}$ & $49.6 \mathrm{~b}$ & $234 b$ & $450 \mathrm{~b}$ & $526 \mathrm{~b}$ & $1209 \mathrm{~b}$ \\
\hline
\end{tabular}

${ }^{2}$ Means within a column followed by the same letter are not significantly different at $P=0.05$ using least significant means.

${ }^{y} \mathrm{Sr}$ treatments were applied after the July sampling date. 
with fruit with four early applications. This suggests higher translocation later in the season. It is also possible that because some fruit were removed after the first four sprays, there may be a bias in comparing fruit $\mathrm{Sr}$ content in September from the last four sprays with fruit Sr content in July from the first four sprays. The highest $\mathrm{Sr}$ content for $\mathrm{Sr}$ sprayed treatments in July was generally found in the core and lowest was in the flesh. In September, for Sr sprayed treatments with fruit uncovered, highest $\mathrm{Sr}$ content was generally in the flesh or peel. When fruit was covered, there was no distinct trend in $\mathrm{Sr}$ distribution within the fruit.

In the control treatments, fruit Sr concentrations (on a weight basis) were about 600-fold lower than $\mathrm{Ca}$ concentrations in July and about 500-fold lower in September (Tables 3 and 4). Despite the large difference in concentrations, $\mathrm{Sr}$ distribution was similar to $\mathrm{Ca}$ with the highest $\mathrm{Sr}$ concentrations in the core and lowest concentrations in the flesh. Similarly, on a content basis, distribution of $\mathrm{Sr}$ in control fruit was similar to $\mathrm{Ca}$ distribution at both sampling dates with the highest $\mathrm{Sr}$ content in the core and lowest in the peel. At the July sampling date, $18 \%, 33 \%$, and $49 \%$ of the fruit Sr was in the peel, flesh, and core, respectively. For comparison, $19 \%, 26 \%$, and $55 \%$ of the fruit $\mathrm{Ca}$ was in the peel, flesh, and core, respectively. At the September sampling date, $23 \%, 35 \%$, and $43 \%$ of the fruit $\mathrm{Sr}$ was in the peel, flesh, and core, respectively. For comparison, $17 \%, 36 \%$, and $47 \%$ of the fruit Ca was in the peel, flesh, and core, respectively. These results further support the idea that $\mathrm{Sr}$ is a suitable tracer for $\mathrm{Ca}$.

Although $\mathrm{Sr}$ distribution in apple fruit was similar to $\mathrm{Ca}$ distribution, discrimination between $\mathrm{Ca}$ and $\mathrm{Sr}$ transport may still exist. Discrimination between $\mathrm{Sr}$ and $\mathrm{Ca}$ transport has been defined as the ratio of $\mathrm{Sr}$ to $\mathrm{Ca}$ in plant tissue relative to the ratio of $\mathrm{Sr}$ to $\mathrm{Ca}$ in soil extracts (Martin et al., 1958):

$\left(\mathrm{Sr}_{\text {plant }} / \mathrm{Ca}_{\text {plant }}\right) /\left(\mathrm{Sr}_{\text {soil }} / \mathrm{Ca}_{\text {soil }}\right)$

Values less than one indicate discrimination against $\mathrm{Sr}$. Higher retention of $\mathrm{Sr}$ compared with $\mathrm{Ca}$ was found in stem tissue of barley (Martin et al., 1958) and wheat (Smith, 1971). Soil Ca concentrations of $2202 \mathrm{mg} \cdot \mathrm{kg}^{-1}$, soil $\mathrm{Sr}$ concentrations of $4.5 \mathrm{mg} \cdot \mathrm{kg}^{-1}$, leaf $\mathrm{Ca}$ and $\mathrm{Sr}$ concentrations from the controls in Table 2 , fruit $\mathrm{Ca}$ concentrations from Table 3 , and fruit $\mathrm{Sr}$ concentrations from the controls in Table 4 were used to calculate discrimination values for this study. Ratios of 0.82 (July) to 1.16 (September) were found for fruit tissue and 0.90 (July) to 0.94 (October) for leaf tissue. Because of the potential discrimination between $\mathrm{Sr}$ and $\mathrm{Ca}$ during transport, it is not possible to unequivocally conclude that $\mathrm{Sr}$ distribution in fruit from foliar and fruit applications would be exactly the same as $\mathrm{Ca}$ applications. However, based on $\mathrm{Ca}$ and $\mathrm{Sr}$ distribution and discrimination values in the controls, it is likely that transport of foliar and fruit-applied $\mathrm{Sr}$ and $\mathrm{Ca}$ is similar.

Results of this study clearly show that fruit $\mathrm{Sr}$ can be increased by $\mathrm{Sr}$ applications to leaves and fruit and that increases are due to both translocation to the fruit from foliar applica- tions as well as direct penetration of the peel and subsequent movement to flesh and core tissue. In contrast, studies with ${ }^{85} \mathrm{Sr}$ applied to leaves and fruit to simulate radioactive fallout have shown little translocation to fruit (Carini and Bengtsson, 2001). Accumulation of radioactivity in apple fruit was restricted to the peel and was the result of direct application to the fruit (Bengtsson, 1992). Similarly, Van Goor (1973) reported little penetration of ${ }^{45} \mathrm{Ca}$ below the skin when applied to the surface of apple fruit. Nine days following application, most of the radioactivity was found within a $1-\mathrm{mm}$ section below the skin. The studies using ${ }^{85} \mathrm{Sr}$ were conducted with high radioactive counts, but very low concentrations of $\operatorname{Sr}\left(<0.012 \mathrm{mg} \cdot \mathrm{L}^{-1}\right.$ $\mathrm{Sr})$. This concentration is about 250,000 times less than the $3080 \mathrm{mg} \cdot \mathrm{L}^{-1} \mathrm{Sr}(35 \mathrm{mM})$ used in our studies, which was selected to simulate $\mathrm{Ca}$ concentrations routinely recommended for foliar application. For the radioactive $\mathrm{Ca}$ studies, the ${ }^{45} \mathrm{Ca}$ was mixed with a high concentration of $\mathrm{Ca}$, but only a $10-\mu \mathrm{L}$ drop was applied to the fruit surface. In contrast, the high concentrations of Sr used in our study were applied to leaves and fruit until runoff.

The results from the ${ }^{85} \mathrm{Sr}$ and ${ }^{45} \mathrm{Ca}$ studies and the foliar and fruit applied $\mathrm{Sr}$ study presented here are all consistent with $\mathrm{Ca}$ transport processes in plants. Movement of $\mathrm{Ca}$ is directly linked to cation exchange processes in the xylem vessels and cell walls of the surrounding tissue (Marschner, 1995). Low concentrations of $\mathrm{Sr}$ or $\mathrm{Ca}$ are likely adsorbed by leaf and peel cell walls and do not move significantly to leaf xylem tissue or to inner parts of the fruit. Similarly, low volumes of high $\mathrm{Ca}$ concentrations applied to the fruit surface would also be adsorbed by cell walls before penetrating deeply below the skin. Known methods to induce transport of foliar-applied $\mathrm{Ca}$ include increasing the concentration of $\mathrm{Ca}$ in the spray solution, adding a chelating agent, injuring the leaf, adding other divalent cations to the spray solution, and increasing the volume of spray solution applied (Hanger, 1979; Swietlik and Faust, 1984). The high $\mathrm{Ca}$ concentrations and volumes used in foliar sprays to control bitter pit will tend to saturate the system and minimize the effects of cation exchange reactions, thus allowing movement beyond surface tissue. The distribution of $\mathrm{Sr}$ in apple fruit found in the present study was likely the result of saturating exchange sites and allowing transport into the tissue from sprayed leaves, as well as direct penetration through the peel.

Assuming that $\mathrm{Sr}$ transport is similar to $\mathrm{Ca}$ transport, an estimate of the maximum $\mathrm{Ca}$ increase in fruit tissue from foliar and fruit applications can be calculated from the $\mathrm{Sr}$ data presented in Table 4. Because $\mathrm{Sr}$ has an atomic weight of about 2.2 times that of $\mathrm{Ca}$, the concentration of $\mathrm{Ca}$ in fruit $\left(\mathrm{mg} \cdot \mathrm{kg}^{-1}\right.$ Ca dry weight) will actually be less than the concentration measured using Sr. Adjusting for the molecular weight of $\mathrm{Ca}$, and based on the observed increase with $\mathrm{Sr}$, the maximum increase in fruit $\mathrm{Ca}$ concentration (dry weight basis) from foliar applications (eight sprays with adjuvant and uncovered fruit) was as fol- lows: core, $78 \mathrm{mg} \cdot \mathrm{kg}^{-1} \mathrm{Ca}$; flesh, $35 \mathrm{mg} \cdot \mathrm{kg}^{-1} \mathrm{Ca}$; peel, $195 \mathrm{mg} \cdot \mathrm{kg}^{-1} \mathrm{Ca}$; entire fruit, $67 \mathrm{mg} \cdot \mathrm{kg}^{-1}$ $\mathrm{Ca}$. On a content basis, Ca would increase by about $1.1 \mathrm{mg}$ per fruit with an average fresh weight of about $140 \mathrm{~g}$. This estimate is lower than those reported by Van Goor (1971), but within the range reported for $\mathrm{Ca}$ applications by Wilkinson (1968).

In conclusion, results from this study suggest that $\mathrm{Sr}$ is a suitable tracer for foliar- and fruit-applied Ca in apple trees. The advantage of using $\mathrm{Sr}$ is derived from background levels of $\mathrm{Sr}$ in soil and plant tissue that are much lower than Ca levels. Of the total $\mathrm{Sr}$ in fruit, about 11 to $17 \%$ can be attributed to translocation from sprayed leaves, confirming that direct spray application to fruit is essential for maximum increases in fruit Sr. Eight spray applications over the growing season more than doubled the concentration and content of fruit Sr compared with four late season sprays. The adjuvant used in this study doubled $\mathrm{Sr}$ absorption by and translocation to fruit compared with no adjuvant. Use of $\mathrm{Sr}$ instead of $\mathrm{Ca}$ in research trials may provide a more precise method of evaluating the efficacy of different adjuvants to increase fruit $\mathrm{Ca}$.

\section{Literature Cited}

Agency for Toxic Substances and Disease Registry (ATSDR). 2004. Toxicological Profile for Strontium. U.S. Dept. of Health and Human Services. http://www.atsdr.cdc.gov/toxprofiles/ tp159.html.

Bengtsson, G.B. 1992. Mobility of superficially applied caesium-134 and strontium- 85 in apples branches under precipitation-free conditions. Analyst 117:1193-1196.

Brown, J.R. 1998. Recommended chemical soil test procedures for the North Central region. Mo. Agr. Expt. Sta. SB 1001.

Carini, F. and G. Bengtsson. 2001. Post-deposition transport of radionuclides in fruit. J. Environ. Radioact. 52:215-236.

Carini, F., M. Brambilla, N. Mitchell, and Z. OuldDada. 2003. Cesium-134 and strontium- 85 in strawberry plants following wet aerial deposition. J. Environ. Qual. 32:2254-2264.

Conway, W.S. and C.E. Sams. 1987. The effects of postharvest infiltration of calcium, magnesium, or strontium on decay, firmness, respiration, and ethylene production in apples. J.Amer. Soc. Hort. Sci. 112:300-303.

Ferguson, I.B. and C.B. Watkins. 1989. Bitter pit in apple fruit. Hort. Rev. 11:289-355

Ferguson, I.B. and C.B. Watkins. 1992. Crop load affects mineral concentrations and incidence of bitter pit in 'Cox's Orange Pippin' apple fruit. J. Amer. Soc. Hort. Sci. 117:373-376.

Hanger, B.C. 1979. The movement of calcium in plants. Commun. Soil Sci. Plant Anal. 10:171-193.

Hutchin, M.E. and B.E. Vaughan. 1968. Relation between simultaneous $\mathrm{Ca}$ and $\mathrm{Sr}$ transport rates in isolated segments of vetch, barley, and pine roots. Plant Physiol. 43:1913-1918.

Kabata-Pendias, A. and H. Pendias. 2001. Trace elements in soils and plants. 3rd ed. CRC Press, Boca Raton, Fla.

Laszlo, J.A. 1994. Changes in soybean fruit $\mathrm{Ca}^{2+}$ $\left(\mathrm{Sr}^{2+}\right)$ and $\mathrm{K}^{+}\left(\mathrm{Rb}^{+}\right)$transport ability during development. Plant Physiol. 104:937-944.

Marschner, H. 1995. Mineral nutrition of higher plants. 2nd ed. Academic Press, London.

Martin, R.P., P. Newbould, and R.S. Russell. 1958. Discrimination between strontium and calcium in 
plants and soils, p. 173-190. In: R.C Extermann (ed.). Radioisotopes in scientific research. vol. 4. Pergamon Press, London

Munter, R.C., T.L. Halverson, and R.D. Anderson. 1984. Quality assurance of plant tissue analysis by ICP-AES. Commun. Soil Sci. Plant Anal. 15:1285-1322.

Perring, M.A. and C.H. Jackson. 1975. The mineral composition of apples. Calcium concentration and bitter pit in relation to mean mass per apple. J. Sci. Food Agr. 26:1493-1502.

Queen, W.H., H.W. Fleming, and J.C. O'Kelley. 1963. Effects on Zea mays seedlings of strontium replacement for calcium in nutrient media. Plant Physiol. 38:410-413.

Rosenberger, D.A., J.R. Schupp, S.A. Hoying, L. Cheng, and C.B. Watkins. 2004. Controlling bitter pit in 'Honeycrisp' apples. HortTechnology
14:342-349.

SAS Institute. 1999. SAS/STAT user's guide. Version 8.02. SAS Institute Inc., Cary, N.C.

Siddiqui, S. and F. Bangerth. 1995. Differential effect of calcium and strontium on flesh firmness and properties of cell walls in apples. J. Hort. Sci. 70:949-953.

Smith, K. 1971. The comparative uptake and translocation by plants of calcium, strontium, barium, and radium II. Triticum vulgare (wheat). Plant and Soil 34:643-651.

Steele, R.G. and J.H. Torrie. 1980. Principles and procedures of statistics. 2nd ed. McGraw-Hill, New York.

Swietlik, D. and M. Faust. 1984. Foliar nutrition of fruit crops. Hort. Rev. 6:287-355.

Tomala, K., M. Araucz, and B. Zaczek. 1989. Growth dynamics and calcium content in McIntosh and
Spartan apples. Commun. Soil Sci. Plant Anal. 20:529-537.

Van Goor, B.J. 1971. The effect of frequent spraying with calcium nitrate solutions on the mineral composition and the occurrence of bitter pit of the apple Cox's Orange Pippin. J. Hort. Sci. 46:347-364.

Van Goor, B.J. 1973. Penetration of surface-applied ${ }^{45} \mathrm{Ca}$ into apple fruit. J. Hort. Sci. 48:261-270.

Vang-Petersen, O. 1980. Calcium nutrition of apple trees: A review. Sci. Hort. 12:1-9.

Wilkinson, B.G. 1968. Mineral composition of apples IX. Uptake of calcium by the fruit. J. Sci. Food Agr. 19:646-7.

Wills, R.B., K.J. Scott, and E.T. Carroll. 1975. Use of alkaline earth metals to reduce the incidence of storage disorders of apples. Austral. J. Agr. Res. 26:169-171. 